\title{
Nitrification performance and microbial community dynamics in a submerged membrane bioreactor with complete sludge retention
}

\author{
Hongyan $\mathrm{Li}^{\mathrm{a}}$, Min Yang ${ }^{\mathrm{a}, *}$, Yu Zhang ${ }^{\mathrm{a}}$, Tao Yu ${ }^{\mathrm{a}}$, Yoichi Kamagata ${ }^{\mathrm{b}}$ \\ ${ }^{a}$ State Key Laboratory of Environmental Aquatic Chemistry, Research Center for Eco-Environmental Science, \\ The Chinese Academy of Science, 18\# Shuangqing Road, Haidian District, Beijing 100085, China \\ ${ }^{\mathrm{b}}$ Research Institute of Biological Resources, National Institute of Advanced Industrial Science and Technology, \\ P.O. 1-1-1, Higashi, Tsukuba, Ibaraki 305-8566, Japan
}

Received 30 March 2005; accepted 3 October 2005

\begin{abstract}
A submerged membrane bioreactor (MBR) supplied with inorganic ammonium-bearing wastewater $\left(\mathrm{NH}_{4}{ }^{+}-\mathrm{N}, 500 \mathrm{mg} \mathrm{l}^{-1}\right)$ was operated for 260 days without sludge purge under decreased hydraulic retention times (HRT) through six steps (from 30 to $5 \mathrm{~h}$ ). Almost complete nitrification was obtained at a volumetric loading rate (VLR) $\leqslant 1.2 \mathrm{~g} \mathrm{NH}_{4}{ }^{+}-\mathrm{N}^{-1} \mathrm{day}^{-1}$. The sludge nitrification activities were evaluated at each stage. The specific ammonium oxidizing rate (SAOR) decreased from the initial 0.45 to $0.15 \mathrm{~kg} \mathrm{NH}_{4}{ }^{+}-\mathrm{N} \mathrm{kg}^{-1}$ MLSS day ${ }^{-1}$ in the last four stages, while the specific nitrate forming rate (SNFR) increased from

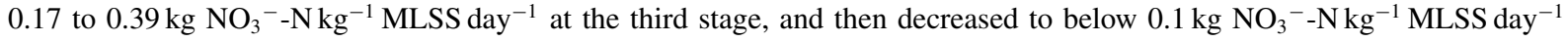
from the fourth stage.

Microbial population dynamics was investigated by a combination of the MPN method, fluorescence in situ hybridization (FISH) and quinone profiles. During the experiment, although the MLSS increased gradually from 4.5 to $11.5 \mathrm{~g}^{-1}$, the number of ammonia-oxidizing bacteria (AOB) decreased from $10^{9} 1^{-1}$ at the third stage to $10^{7} 1^{-1}$ in the last two stages, and that of nitrite-oxidizing bacteria (NOB) decreased gradually from $10^{8} 1^{-1}$ at the second stage (HRT of $20 \mathrm{~h}$ ) to the final $10^{5} 1^{-1}$. FISH results showed that the active cells decreased gradually with time from about 60 to $20 \%$ in the last two stages, and most of sludge was inert cells. The sum of nitrifiers occupied only about $10 \%$ of the total bacteria number in the last stage even though only ammonium-bearing inorganic wastewater was fed in. Nitrosomonas sp. and Nitrospira sp. were confirmed by FISH as the dominant nitrifying genera responsible for ammonia and nitrite oxidation, respectively. In the mean time, a small ratio of Nitrobacter sp. also existed in the system. FISH analysis matched better with the batch activity test results than did the MPN techniques. Quinone profiles revealed that the dominant ubiquinone was ubiquinone-8 (UQ-8), ranging from 84 to $66 \%$, followed by UQ-10 of 7-13\%, UQ-7 of 3-5\% and UQ-9 of 1.6-2.6\%. The dominant menaquinone in the MBR was menaquinone-7 (MK7) followed by MK-6, MK-8 and MK-8 $\left(\mathrm{H}_{2}\right)$. With the prolongation of operation, the percentage of menaquinones increased from 8 to $14 \%$. The use of the polyphasic approach gave some new insight on variations of microbial community structures. (C) 2005 Elsevier B.V. All rights reserved.
\end{abstract}

Keywords: Microbial community structure; Quinone; Fluorescence in situ hybridization (FISH); Nitrifying activities; MBR

\footnotetext{
* Corresponding author. Tel.: +86 1062923475 ; fax: +86 1062923541.

E-mail address: yangmin@mail.rcees.ac.cn (M. Yang).
} 


\section{Introduction}

Although biological nutrient removal systems have achieved worldwide acceptance, they should be improved in terms of their reliability and costeffectiveness (Rittmann, 2002). Membrane bioreactors (MBR), which permit a very long sludge retention time (SRT), high mixed liquor suspended solids (MLSS) and low F/M ratio due to the interception of the membrane, have been found to be advantageous over the conventional activated sludge system in terms of system stability and compactness, especially for nitrification (Luxmy et al., 2000; Rosenberger et al., 2002; Stamper et al., 2003). However, how to operate MBR systems efficiently remains a topic of argument because of the lack of sufficient information on the development of microbial community structure in MBRs during nitrification.

Recent development of molecular biological techniques and chemotaxonomy methods has offered an opportunity for analysis of microbial community structures and a sounder basis for engineering their control (Hu et al., 2001; Kurisu et al., 2002; Rittmann, 2002). No single method, however, is enough to provide a comprehensive view of the complex microbial community structures for biological wastewater treatment systems. For example, PCR-DGGE, a molecular method by which DNA fragments of the same length but different base pair sequences can be separated and bands can further be excised from gel and sequenced to identify the phylogenetic affiliation of the community members, may contain biases stemming from DNA extraction, PCR amplification and the detection of heteroduplex molecules (Che et al., 2003). Fluorescence in situ hybridization (FISH), which can be used to trace specific functional groups in biological systems, is limited to those for which probes are available. Quinone profiles, which could possess a very high sensitivity and repeatability by use of the HPLC-MS-APCI method (Gao et al., 2003), can only reveal the structure at the 'phylum' level and some phylogenetically different groups of bacterium that share the same quinone groups (Kurisu et al., 2002). Therefore, a combined approach using several analytical methods is indispensable to comprehensively determine the microbial community structure in a biosystem.

In a previous study, the nitrification performance and microbial community structure of an MBR were compared with those of a conventional activated sludge (CAS) system by treating synthetic ammonia-bearing inorganic wastewater under different HRT conditions (Li et al., 2005). It was found that the MBR had better loading tolerance and richer microbial community diversity under the condition of no sludge purge. Sequence analysis of relevant bands in DGGE gels indicated that Nitrosomonas sp. and Nitrospira sp. were the dominating nitrifiers in the bioreactors.

To reconfirm the above results and obtain a comprehensive understanding of the microbial population dynamics in MBR, in this study, a polyphasic approach incorporating the bench tests, conventional culture technique, microscopic observations, FISH and quinone analysis was used to examine the microbial characteristics for the same system. The sensitivity of each method for evaluating the biological capabilities was also compared.

\section{Materials and methods}

\subsection{Experimental scheme}

The scheme of the experiment was reported as in a previous study (Gao et al., 2004). The membrane bioreactor had an 181 operating volume and a submerged hollow fiber membrane module (pore size, $0.4 \mu \mathrm{m}$; surface area, $0.2 \mathrm{~m}^{2}$; Mitsubishi Rayon Co. Ltd., Tokyo) was mounted on the MBR. The permeate flux was suctioned by a metric pump controlled with a timer. An operational cycle included 4 min of extraction and a 1 min break. A constant air flow of $50 \mathrm{~m}^{3} \mathrm{~m}^{-2} \mathrm{~h}^{-1}$ was supplied from the bottom of the reactor to prevent sludge from forming cake on the surface of the membrane. The dissolution oxygen (DO) was maintained at $4-6 \mathrm{mg} \mathrm{l}^{-1}$ during the whole experiment. The reactor was operated at $20 \pm 1{ }^{\circ} \mathrm{C}$ with the $\mathrm{pH}$ controlled at 7.5-8.0. The composition of the synthetic wastewater was as follows: $\mathrm{NH}_{4} \mathrm{HCO}_{3} 2.8 \mathrm{~g}^{-1}$, $\mathrm{NaHCO}_{3} 3 \mathrm{gl}^{-1}, \mathrm{~K}_{2} \mathrm{HPO}_{4} 2.1 \mathrm{gl}^{-1}, \mathrm{MgSO}_{4} \cdot 7 \mathrm{H}_{2} \mathrm{O}$ $1.4 \mathrm{gl}^{-1}, \quad \mathrm{MnSO}_{4} \cdot 4 \mathrm{H}_{2} \mathrm{O} 276 \mathrm{mgl}^{-1}, \mathrm{FeSO}_{4} \cdot 7 \mathrm{H}_{2} \mathrm{O}$ $400 \mathrm{mgl}^{-1}, \mathrm{CaCl}_{2} \cdot 2 \mathrm{H}_{2} \mathrm{O} 300 \mathrm{mgl}^{-1}$ and some trace elements.

The HRT was varied as follows: stage 1: $30 \mathrm{~h}, 30$ days; stage 2: $20 \mathrm{~h}, 90$ days; stage 3: $15 \mathrm{~h}, 30$ days; stage $4: 10 \mathrm{~h}, 30$ days; stage $5: 7 \mathrm{~h}, 40$ days; stage $6: 5 \mathrm{~h}$, 40 days. Seed sludge was taken from an MBR which 
had been used for the treatment of synthetic inorganic wastewater for about 1 year (Gao et al., 2004). During the duration of the experiment (260 days), sludge was not removed from the system except for sampling, and therefore the sludge retention time (SRT) was increased from 135 days, via 215, 225, 317, 349 to 413 days with the elongation of operation.

\subsection{Batch experiments}

Batch tests were performed to evaluate the variations of nitrification activities of activated sludge in the bioreactor. The flask was inoculated with $0.15 \mathrm{~g}$ (dry weight) sludge from the MBR after washing for three times with tap water. A predetermined amount of stock $\mathrm{NH}_{4} \mathrm{HCO}_{3}$ solution was added to give an initial $\mathrm{NH}_{4}{ }^{+}-$ $\mathrm{N}$ concentrations of $50 \mathrm{mg} \mathrm{l}^{-1}$. Samples were taken at an interval of $30 \mathrm{~min}$, and the $\mathrm{NH}_{4}{ }^{+}, \mathrm{NO}_{2}{ }^{-}, \mathrm{NO}_{3}{ }^{-}$and MLSS were analyzed following filtration according to the Standard Methods (APHA). Specific ammonia oxidizing rate (SAOR) and specific nitrate forming rate (SNFR) were calculated by monitoring the decreased rate of $\mathrm{NH}_{4}{ }^{+}-\mathrm{N}$ concentration and the increased rate of $\mathrm{NO}_{3}{ }^{-}-\mathrm{N}$ concentration versus times, respectively. Since the nitrifiers have a slow growth rate, it was considered that the biomass concentration was a constant during the batch tests.

\subsection{Most probable number (MPN) enumeration}

Basal medium for the MPN enumeration of ammonia oxidizers contained $\left(\mathrm{NH}_{4}\right)_{2} \mathrm{SO}_{4}, 200 \mathrm{mg}$; $\mathrm{K}_{2} \mathrm{HPO}_{4}, 100 \mathrm{mg} ; \mathrm{MgSO}_{4} \cdot 7 \mathrm{H}_{2} \mathrm{O}, 50 \mathrm{mg} ; \mathrm{NaCl}$, $200 \mathrm{mg} ; \mathrm{FeSO}_{4} \cdot 7 \mathrm{H}_{2} \mathrm{O}, 40 \mathrm{mg}$; and $\mathrm{CaCO}_{3} \cdot 2 \mathrm{H}_{2} \mathrm{O}$, $500 \mathrm{mg}$, in $100 \mathrm{ml}$ filter sterile deionized water. Basal medium for the MPN enumeration of nitrite oxidizers contained $\mathrm{NaNO}_{2}, 100 \mathrm{mg}$; $\mathrm{NaCO}_{3}, 100 \mathrm{mg}$; $\mathrm{K}_{2} \mathrm{HPO}_{4}, 50 \mathrm{mg} ; \mathrm{MgSO}_{4} \cdot 7 \mathrm{H}_{2} \mathrm{O}, 50 \mathrm{mg}$; $\mathrm{NaCl}, 50 \mathrm{mg}$; and $\mathrm{FeSO}_{4} \cdot 7 \mathrm{H}_{2} \mathrm{O}, 40 \mathrm{mg}$ in $100 \mathrm{ml}$ filter sterile deionized water. One millilitres sample taken from the reactor was dispersed by sonication. Serial 10 -fold dilutions of the inoculum sources were prepared in sterile distilled water and $1 \mathrm{ml}$ portions were transferred to MPN tubes containing $9 \mathrm{ml}$ of the enumeration medium. Five replicate tubes were prepared per dilution for enumeration. Inoculated MPN tubes were incubated for 5 weeks at $28^{\circ} \mathrm{C}$. Production and oxidization of nitrite in each tube were examined by colour determi- nation after adding zinc powder and Griess reagent, respectively.

\subsection{FISH analysis}

The activated sludge samples extracted at different HRT conditions were fixed for $3 \mathrm{~h}$ with $4 \%$ paraformaldehyde, and then stored in a 1:1 mixture of phosphate-buffered saline (PBS, pH 7.4) and ethanol at $-20^{\circ} \mathrm{C}$. Before hybridization the samples were dispersed into individual cells by ultrasonication, and placed in wells on the gelation-coated microscopic slides. The hybridization and washing procedures were carried out in accordance with a previously described protocol (Amann et al., 1995). The 16S rRNA-targeted oligonucleotide probes and the stringency used in this study are listed in Table 1. Mobarry et al. (1996) has reported that Nso 190 and Nso 1225 encompass all sequenced ammonia oxidizers of the $\alpha$ subclass of Proteobacteria. However, some investigations showed that there was a sequence mismatch between the probe sequence (both Nsol90 and Nso1225) and the target sequence of the bacteria of one or a few bases (Purkhold et al., 2000; Hesselsoe et al., 2001; Persson et al., 2002). So, in this study NSO190 together with NSO1225 was applied to investigate the population dynamics of ammonia oxidizers.

Fluorescent hybridized cells were examined using an epifluorescent microscope (Axioskop2 mot plus, Zeiss Corp., Germany) equipped with a cooled CCD camera (AxioCam MRm, Zeiss Corp., Germany). All image processing and analysis were performed with the standard software package provided by Zeiss (Axio Vision 4.1).

For each condition, two samples were taken. At least 20 different fields (each containing more than 1000 cells) were examined for each sample and probe. Thus, more than 40 views were obtained and averaged for each data point mentioned.

\subsection{Microbial quinone analysis by LC-MS}

Microbial quinones in the system were analyzed using previously described methods (Gao et al., 2003). Quinones were initially extracted from the centrifuged microbes using a mixture of chloroform-methanol and subsequently extracted in hexane. The mixture of crude quinones was purified using Sep-Pak ${ }^{\circledR}$ Plus 
Table 1

Oligonucleotide probes used in this study

\begin{tabular}{llcll}
\hline Probe & Probe sequence $\left(5^{\prime}-3^{\prime}\right)$ & Target site $^{\mathrm{a}}$ & $\%$ FA & Ref. \\
\hline Ntspa662 & GGAATTCCGCGCTCCTCT & $662-680$ & 35 & Daims et al. (2000) \\
NSO1225 & CGCCATTGTATTACGTGTGA & $1225-1244$ & 35 & Mobarry et al. (1996) \\
NSO190 & CGATCCCCTGCTTTTCTCC & $190-208$ & 55 & Mobarry et al. (1996) \\
Nsv443 & CCGTGACCGTTTCGTTCCG & $444-462$ & 30 & Mobarry et al. (1996) \\
NEU & CCCCTCTGCTGCACTCTA & $653-670$ & 40 & Wagner et al. (1995) \\
CTE & TTCCATCCCCCTCTGCCG & $659-676$ & 40 & Luxmy et al. (2000) \\
NIT3 & CCTGTGCTCCATGCTCCG & $1035-1048$ & Wagner et al. (1996) \\
CNIT3 & CCTGTGCTCCAGGCCTCCG & $1035-1048$ & 20 & Wagner et al. (1996) \\
EUB338 & GCTGCCTCCCGTAGGAGT & $338-355$ & Amann et al. (1990) \\
NonEUB & ACTCCTACGGGAGGCAGC & & Wallner et al. (1993) \\
\hline
\end{tabular}

a $16 \mathrm{~S}$ rRNA position according to Escherichia coli numbering.

Silica (Waters Corp., USA). Quinone components were separated and identified using a Waters 2690 HPLC equipped with a mass spectrograph (Micromass ZMD, Waters Corp., USA) and an ODS column (ZorbaxODS, $4.6 \mathrm{~mm} \times 250 \mathrm{~mm}$, Shimadzu-Dupont). UQ-6, 10 and Vitamin K1, purchased from Sigma Corp. (USA), were used as the quantitative standards for ubiquinones and menaquinones, respectively, with a hypothesis of equal mole absorbability.

\section{Results and discussion}

\subsection{Nitrification performance}

Nitrification performance under different nitrification loading rates is shown in Fig. 1. Almost complete ammonium removal was obtained at a volumetric loading rate $(\mathrm{VLR}) \leqslant 1.2 \mathrm{~g} \mathrm{NH}_{4}{ }^{+}-\mathrm{Nl}^{-1}$ day $^{-1}$ $(\mathrm{HRT} \geqslant 10 \mathrm{~h})$ although nitrite accumulation began to

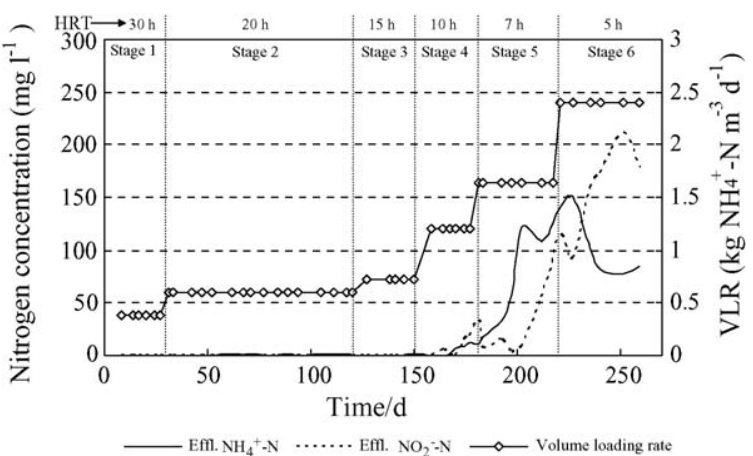

Fig. 1. Variations of effluent $\mathrm{NH}_{4}{ }^{+}-\mathrm{N}, \mathrm{NO}_{2}{ }^{-}-\mathrm{N}$ and $\mathrm{VLR}$ vs. time. occur. When the VLR was increased to $1.63 \mathrm{~g} \mathrm{NH}_{4}{ }^{+}-$ $\mathrm{N}^{-1}$ day $^{-1}$ by reducing the HRT to $7 \mathrm{~h}$, however, significant accumulation of $\mathrm{NH}_{4}{ }^{+}-\mathrm{N}$ appeared (up to $125 \mathrm{mg} \mathrm{l}^{-1}$ ) on day 200. With the further increase of VLR to $2.4 \mathrm{~g} \mathrm{NH}_{4}^{+}-\mathrm{Nl}^{-1}$ day $^{-1}(\mathrm{HRT}=5 \mathrm{~h})$, marked accumulation of $\mathrm{NO}_{2}{ }^{-}-\mathrm{N}$ was observed.

\subsection{Biomass vitality}

The specific ammonium oxidizing rate (SAOR) and specific nitrate forming rate (SNFR) were measured to monitor the biomass vitalities, as shown in Figs. 2 and 3. The difference between SAOR and SNFR could express the extent of nitrite accumulation in the MBR. The SAOR decreased from 0.4 to $0.15 \mathrm{~kg} \mathrm{NH}_{4}^{+}-\mathrm{N} \mathrm{kg}^{-1}$ MLSS day ${ }^{-1}$ in the third stage, and then remained almost unchanged. On the other hand, the SNFR increased from $0.17 \mathrm{~kg} \mathrm{NO}_{3}{ }^{-}-\mathrm{N} \mathrm{kg}^{-1}$ MLSS day ${ }^{-1}$ at the first stage to $0.39 \mathrm{~kg} \mathrm{NO}_{3}{ }^{-}-\mathrm{N} \mathrm{kg}^{-1} \mathrm{MLSS}^{-1}{ }^{-1}$ at the third stage,

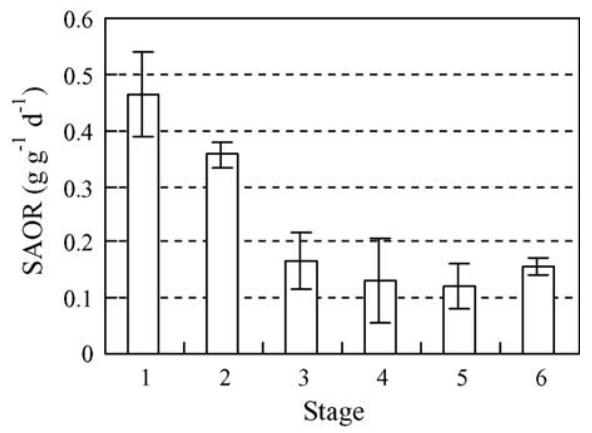

Fig. 2. Variation of $\mathrm{NH}_{4}{ }^{+}-\mathrm{N}$ oxidizing rate in MBR. 


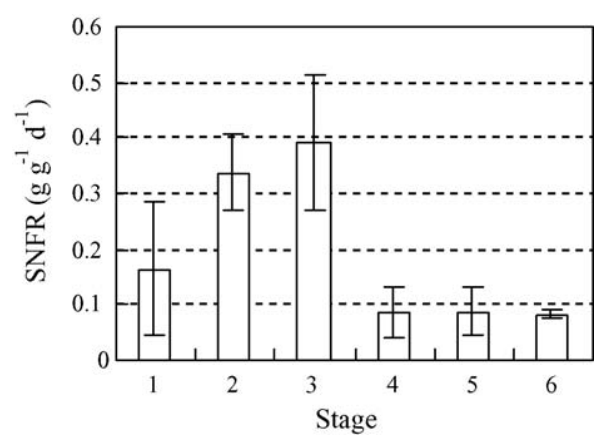

Fig. 3. Variation of $\mathrm{NO}_{3}{ }^{-}-\mathrm{N}$ formation rates in $\mathrm{MBR}$.

and then decreased significantly to $0.08 \mathrm{~kg} \mathrm{NO}_{3}{ }^{-}$ $\mathrm{N} \mathrm{kg}^{-1}$ MLSS day ${ }^{-1}$ at the fourth stage.

Despite the decreasing trend of SAOR during the first three periods, complete nitrification was achieved due to the relatively low influent $\mathrm{NH}_{4}{ }^{+}-\mathrm{N}$ loads, as shown in Fig. 4. At the fourth stage, while the ammonium oxidation capacity of the system was enough for converting all of the ammonium fed, the nitrate formation capacity was a little short for complete nitrite conversion, resulting in the partial accumulation of nitrite. In the last two stages, the influent $\mathrm{NH}_{4}{ }^{+}-\mathrm{N}$ loads exceeds the capacities of both ammonium oxidizers and nitrite oxidizers, which was confirmed by the performance of the reactor (Fig. 1).

It is clear that activity-based method was useful for speculating nitrification performance in the MBR. However, activity-based measurements do not explain why the nitrification activities were high or low or sta-

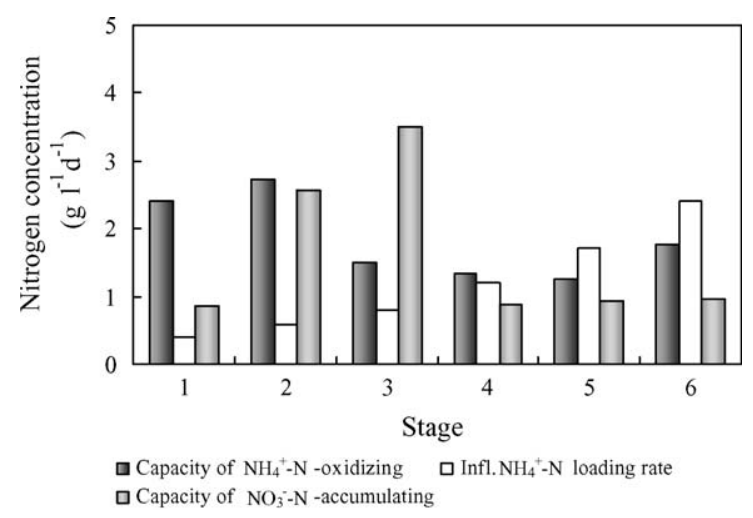

Fig. 4. Comparison of ammonia received and accepted at each condition.

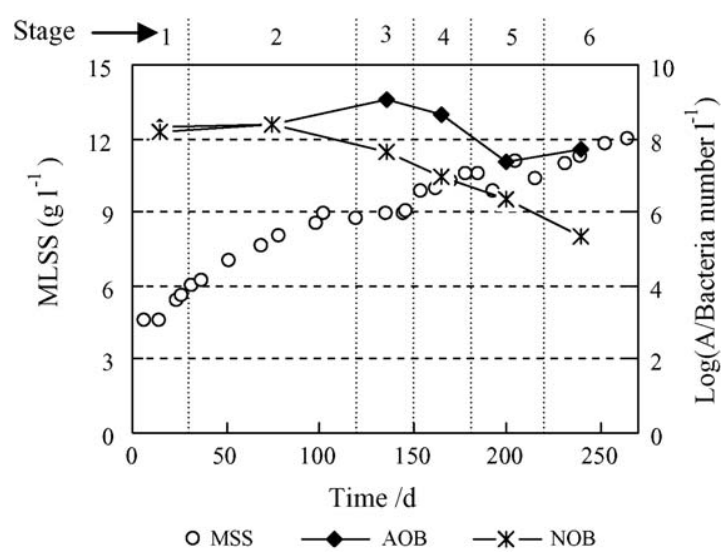

Fig. 5. Variations of the number of nitrifiers and MLSS vs. time.

ble during the operation. So, a polyphasic approach including the conventional culture technique, microscopic observations FISH and quinone analysis was used to examine the microbial characteristics in the system.

\subsection{Variations of nitrifiers}

Variations of nitrifiers counted with the MPN method are shown in Fig. 5 together with the variations of MLSS. The number of ammonia-oxidizing bacteria (AOB) decreased from $10^{9} 1^{-1}$ at the third stage to $10^{7} 1^{-1}$ in the last two stages, and that of nitrite-oxidizing bacteria (NOB) decreased gradually from $10^{8} 1^{-1}$ at the second stage (HRT of $20 \mathrm{~h}$ ) to the final $10^{5} 1^{-1}$. It could be seen that the low SAOR and SNFR in the last three stages were clearly related to the low levels of AOB and NOB in the bioreactor. However, the variations of nitrifiers were not consistent with the developments of the SAOR and SNFR, suggesting that cell count was not sensitive enough to reflect the metabolic behaviors of microorganisms in the bioreactor.

On the other hand, Fig. 5 shows that the MLSS increased gradually from the initial $4.5 \mathrm{~g}^{-1}$ to the final $11.5 \mathrm{~g}^{-1}$ under the interception of the membrane. But, the number of nitrifiers did not increase accordingly, which was contradictory to the common assumption that the interception of the membrane is helpful for keeping the low growing nitrifiers in the biosystem. This increase of MLSS was probably attributed to 


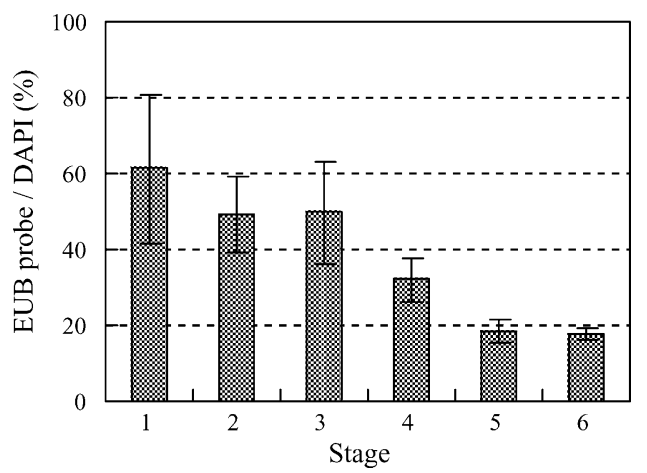

Fig. 6. The fraction of alive cells in the total bacteria measured by FISH.

the accumulation of extracellular polymeric substances (EPSs) and inert matters under long SRTs. Scanning electron microscopy (SEM) showed that the longer the system ran, the more gluey matter was enwrapped around the zoogloea (Li et al., 2005).

\subsection{FISH analysis}

The detectability of bacteria by FISH is dependent on their ribosomal content and consequently on their physiological state. Cells with low rRNA contents were often associated with dormant, starved or very slowly growing states with a low metabolic activity (Witzig et al., 2002). So, in this study, the total bacterial number was counted by DAPI staining, and only the EUB probe-positive cells were considered as active (Kurisu et al., 2002). As shown in Fig. 6, more than half of the bacteria in all DAPI-stained cells gave a clear fluorescence signal in the beginning. However, the EUB/DAPI ratio decreased gradually with time, and was only $20 \%$ during the last two stages. This indicated that the inter- ception of membrane played an important role in the accumulation of inert cells.

Fig. 7A shows that AOB represented by the NSO190 and NSO1225 specific bacteria, which contain all the sequenced ammonia oxidizers in the beta subclass of Proteobacteria (including Nitrosomonas, Nitrosococcus mobilis, Nitrosospira, Nitrosovibrio and Nitrosolobus) (Mobarry et al., 1996), were the dominant fractions in the EUB338-hybridized microorganisms in the beginning. The ratio of AOB/EUB338, however, deceased continuously from the initial $57-23 \%$, indicating that the environment did not favor the growth of AOB. On the other hand, the ratio of AOB detected by these two probes to the total bacterial number (DAPI-stained) presented a decreasing trend with time, which was coincided with those of SAOR (Fig. 2). The accumulation of dead cells and EPS by the interception of the membrane under a long SRT might affect the metabolism behavior of ammonium oxidizers. Hasar et al. $(2002,2003)$ also reported the decrease of biomass viability by 50 and $90 \%$, respectively, in a submerged membrane bioreactor when treating domestic wastewater treatment at MLSS $<15 \mathrm{~g} \mathrm{l}^{-1}$ and raw whey wastewater at MLSS of $60-90 \mathrm{~g}^{-1}$ with no sludge purge.

Fig. 7B shows that part of AOB belongs to Nitrosomonas $\mathrm{spp}$., which can be detected by the NEU probe, indicating that at least two populations of $\mathrm{AOB}$ were present. But, no Nitrosospira-like bacteria, which were reported recently to be the main AOB in the nitrifying aggregates based on the application of molecular methods (Stephen et al., 1996; Schramm et al., 1998), were detected in the samples using NSV443 probe. The difference in the findings was probably due to the fact that the $\mathrm{NH}_{4}{ }^{+}$concentration used in this study was high compared to the concentration used in the studies of Stephen and Schramm. The fraction of Nitrosomonas
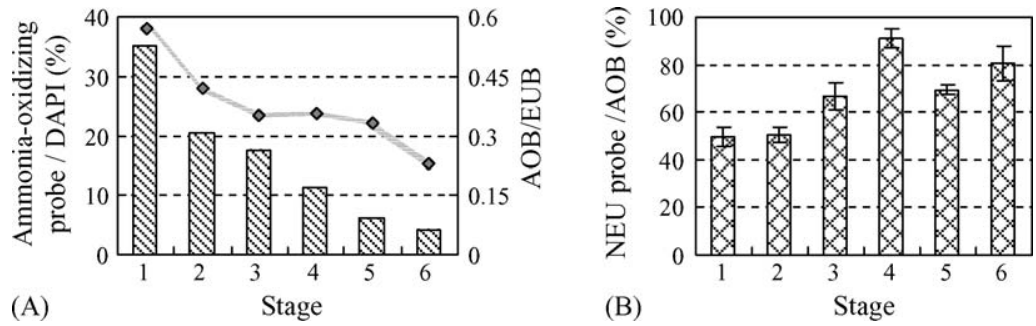

Fig. 7. Bacterial composition of AOB measured by FISH. 


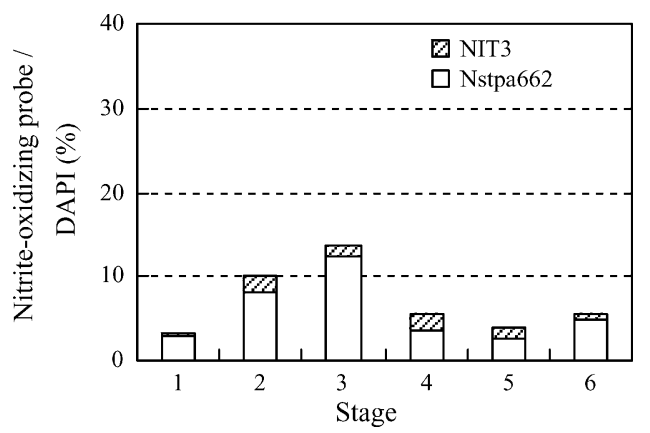

Fig. 8. Bacterial composition of NOB measured by FISH.

spp. in AOB gradually increased from 50 to $90 \%$ with time, which was in accordance with the result reported by Mobarry et al. (1996) that the predominant AOB in ammonium-rich systems was the members of the genus Nitrosomonas. The increasing proportion of Nitrosomonas spp. in the MBR could explain the relatively stable ammonia oxidizing capacity under the decreasing AOB numbers, since Nitrosomonas spp. is typical $\gamma$ strategist with remarkably high $K_{\mathrm{s}}$ values from the points of ammonium oxidation kinetics and the growth rate (Stehr et al., 1995).

Fig. 8 reveals that the MBR contained two different groups of NOB, i.e. an NIT3-positive one (Nitrobacter) and an Nstpa662-positive one (Nitrospira-like). The number of Nitrobacter species was much lower than that of Nitrospira species over the whole experimental period. We were not able to detect Nitrobacter-type bacteria by the PCR-DGGE technique in the previous study (Li et al., 2005), perhaps due to the relatively low cell number. It is interesting that the decrease of NOB occurred from the fourth stage, which exhibited a good agreement with the change in SNFR mentioned above (Fig. 3). One possible factor for inhibiting the nitrite oxidation activities is the increase of free ammonia (FA) concentrations. Anthonisen et al. (1976) reported an inhibition of Nitrobacter at free ammonia (FA) concentrations between 0.1 and $1 \mathrm{mg} \mathrm{NH} \mathrm{N}^{-1}$. In this study, an FA concentration of $1-10 \mathrm{mg} \mathrm{NH}_{3} \mathrm{l}^{-1}$ was reached during stages 4,5 and 6 when $\mathrm{NH}_{4}{ }^{+}-\mathrm{N}$ concentrations in the effluent were $10-150 \mathrm{mg} \mathrm{l}^{-1}$ under an $\mathrm{pH}$ of 7.5-8.0.

Figs. 7A and 8 demonstrate that the FISH technique was more accurate and reliable than the MPN counting technique in characterizing the nitrifier activity levels and microbial community dynamics. The main problem of the MPN method is attributed to the fact that only a small quantity of microorganism could be cultured. Especially for Nitrospira sp., it is extremely difficult to cultivate and cannot be quantified by culture methods (Dionisi et al., 2002).

In the last stage, the number of AOB was comparative to that of NOB, and the sum of the two populations occupied only about $10 \%$ of the total bacteria number, indicating that it is difficult to maintain a nitrifier dominant system in the MBR operated under a long SRT (135-413 days) even when only ammonium-bearing inorganic wastewater was fed in. The long SRTs might be one possible reason for the continuous decrease of nitrifiers. It is not clear, however, why AOB and NOB showed different variation patterns. One possibility is the existence of some unknown lithoautotrophic AOBs or heterotrophic AOBs (Witzig et al., 2002), since the SAOR did not decreased much during last four stages (Fig. 2).

\subsection{Quinone profiles}

Variations of quinone profiles at each stage are shown in Figs. 9 and 10. The composition of ubiquinone was much simpler than that of menaquinone. Four types of ubiquinone (UQ-7, UQ-8, UQ-9 and UQ-10) were found in all samples and they accounted for more than $85 \%$ of the quinones over the whole experimental period.

Fig. 9 shows that UQ-8 was the most abundant one and it accounted for more than $66 \%$ during the

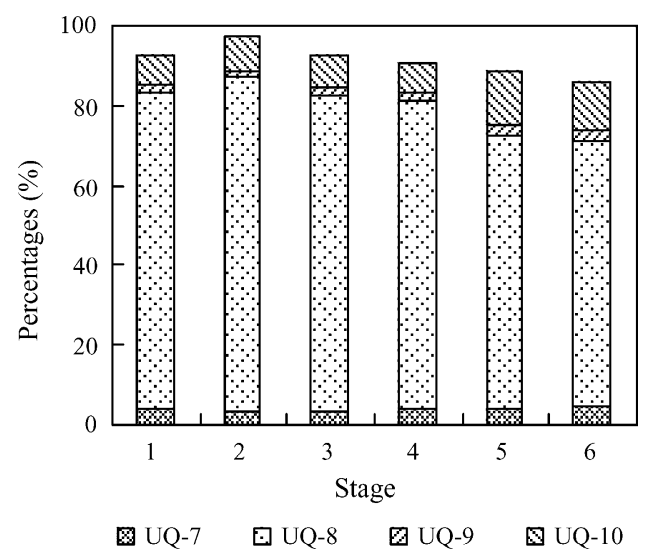

Fig. 9. Ubiuinone profiles of samples. 
whole experiment. Previous studies have indicated that bacteria containing UQ-8 in the activated sludge may represent subclass $\beta$-Proteobacteria (including almost all AOB) (Hiraishi et al., 1996; Tang et al., 2003). In the case of ammonium, as the only substrate-like material for growth like this study, the UQ-8 content may represent the ratio of $\mathrm{AOB}$ in the MBR system. The decrease of UQ-8 content from 78\% in the second stage to $66 \%$ in the last two stages was also coincided with the results of FISH analysis. The second dominant ubiquinone was UQ-10 (7-13\%), followed by UQ-7 (3-5\%) and UQ-9 (1.6-2.6\%). There have been several previous reports claiming that subclass $\alpha$ - and $\gamma$-Proteobacteria are the representative bacteria containing UQ-10 and UQ-9, respectively, as a major quinone (Hiraishi, 1999; Tang et al., 2003). Although it is known that Nitrobacter sp. belongs to subclass $\alpha$-Proteobacteria and Nitrcoccus mobilis belongs to subclass $\gamma$-Proteobacteria (Juretschko et al., 1998; Dionisi et al., 2002; Lim et al., 2004), it was difficult to correlate the NOBs with quinone profiles in this study.

Fig. 10 shows that the sludge system contained 7-12 types of menaquinone. MK-7 (2-6\%), followed by MK-6 (1.8-2.8\%) and MK-8 (about 1.5\%), was the major menaquinone. There were also trace amounts of MK-9 $\left(\mathrm{H}_{8}\right)$, MK-8 $\left(\mathrm{H}_{2}\right)$, MK-9 $\left(\mathrm{H}_{2}\right),-7\left(\mathrm{H}_{2}\right)$, $-9,-10,-10\left(\mathrm{H}_{4}\right),-8\left(\mathrm{H}_{4}\right)$ and $-6\left(\mathrm{H}_{2}\right)$ in the sludge. MK-7 and MK-6 are found in Gram-positive bacteria with a low $\mathrm{G}+\mathrm{C}$ content, as well as $\delta$ and $\varepsilon$-subclass Proteobacteria and members of the

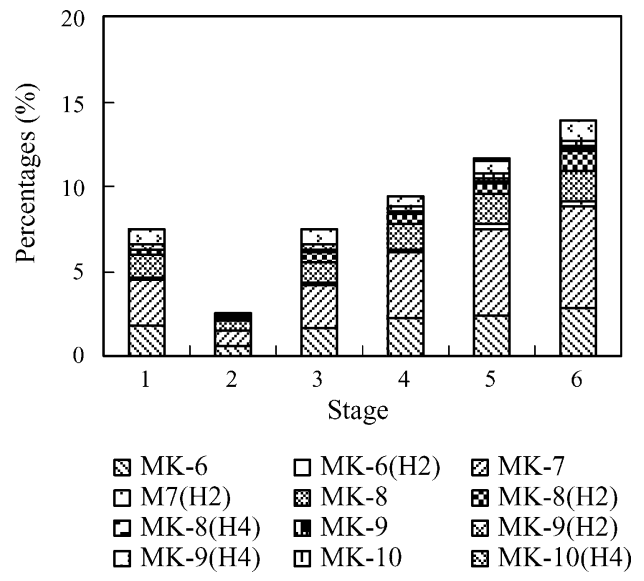

Fig. 10. Menaquinone profiles of samples.
Cytophaga-Flavobacterium cluster. The detection of MK-8 might be an indicative of Gram-positive bacteria with a low $\mathrm{G}+\mathrm{C}$ content, as well as $\delta$ - and $\varepsilon$-subclass Proteobacteria and Actinobacteria existed in the MBR (Tang et al., 2003). Our previous study indicated the existence of Flavobacterium spp. in the MBR treating the same inorganic wastewater ( $\mathrm{Li}$ et al., 2005). These species could do respiration using nitrate as the electron accepter when oxygen is limited and it is speculated that they grew on the EPS formed by active nitrifiers and dead cells. Tsuneda et al. (2003) also reported the development of heterotrophs inside the nitrifying granules although the organic matter was not contained in the feed solution.

Ubiquinones and menaquinones have been considered to be the respective indicators of aerobic bacteria and anaerobic bacteria (Hedrick and White, 1986), because ubiquinones and menaquinones are involved in aerobic and anaerobic respirations, respectively (Hirashi Akira, 1999). Considering the strong aeration condition $\left(50 \mathrm{~m}^{3} \mathrm{~m}^{-2} \mathrm{~h}^{-1}\right)$ in the bioreactor, it is difficult to think that oxygen supply might be the problem. However, oxygen transfer limitations might occur inside the floes of activated sludge due to the increase of EPSs (Lübbeke et al., 1995; Muller et al., 1995). So, the increase of menaquinones from 8 to $14 \%$ with the prolongation of operational period, except for period 2 , in the nitrification system was probably related with the existence of nitrate/nitrite respiration because of the limitation of oxygen transfer.

Since Nitrobacters belonging to $\alpha$-Proteobacteria accounted for only about 1-2\% of total bacteria by FISH analysis, it was estimated that the marked increase of UQ-10 was caused by other $\alpha$ Proteobacteria bacteria other than Nitrobacters. The bacteria most closely related to the Nitrobacter species but physiologically distinct within the alpha subdivision are Methylobacterium (Teske et al., 1994; Alzerreca et al., 1999), which are speculated to grow on EPSs formed by active nitrifiers and dead cells. Davies and Wittenbury (1970) has indicated that they have similar introcytoplasmic membrane structures, a feature that ties them both to the phototrophs. Previous investigations revealed that UQ-7 plays an important role in the photosynthesis of some phototrophs (Takamiya and Nishimura, 1975). This could explain why UQ-7 was detected in the bioreactor. The peripheral affiliations of UQ-10, UQ-7 with nitrifiers, methylotroph 
and prototroph should be noted, and these relationships require further study.

On the other hand, the $\gamma$-Proteobacteria (representative bacteria of UQ-9) harbors the ammonia oxidizer Nitrosococcus oceanus and the nitrite oxidizer N. mobilis (Teske et al., 1994). The detection of UQ9 in the bioreactor might imply the existence of these species. So far, however, few probes for AOB of the $\gamma$-Proteobacteria have been described (Bothe et al., 2000). Further conclusions on these two species must be drawn using the combined molecular methods.

\section{Conclusions}

The population dynamics of nitrifying bacteria and their activities were monitored to evaluate how long SRTs and the increasing influent loadings by decreasing the HRT affected nitrification performance in an MBR using a polyphasic approach of batch test, MPN, FISH and quinone profile techniques. The following conclusions are drawn.

Under the interception of membrane, sludge concentration in the reactor gradually increased with the elongation of time. However, MPN and FISH detection results revealed the deceasing trend of nitrifiers. Consequently, the capacities of ammonium oxidation and nitrate formation in the bioreactor decreased, $\alpha, \beta$ and $\gamma$ subclasses of Proteobacteria containing UQ-10, UQ-8 and UQ-9 as the major quinones, respectively, were the dominant microorganisms in the bioreactor. Nitrosomonas sp. and Nitrospira-like bacteria were identified as the predominant nitrifiers in the MBR. Some Nitrobacter sp. also existed in the system. The increasing trend of menaquinones and decreasing trend of EUB338-stained cells suggest that inert materials accumulated in the MBR under a long SRT attributed by the complete sludge retention. Operating the system under a controlled SRT might be important to keep the biosystem with a high activity.

Activity-based measurements and microbial methods assess different aspects of microbial function and community. Activity-based methods give a direct estimate of system performance. The cell counting results could be used to characterize the nitrification activities and bioreactor performance to some extent, whereas the FISH technique is more accurate and reliable in characterizing the nitrifier activity levels and micro- bial community dynamics. Combined with the FISH technique, the quinone profile could also give some important indications of variations of microbial community structures. In a word, a polyphasic approach using different methods is required to analyze a complicated biosystem.

\section{Acknowledgements}

Funding for this research was provided by the National Natural Science Foundation of China (Grant No. 20521140076) and (Grant No. 50238050).

\section{References}

Alzerreca, J.J., Norton, M.J., Klotz, G.M., 1999. The amo operon in marine, ammonia-oxidizing $\gamma$-Proteobacteria. FEMS Microbiol. Lett. 180, 21-29.

Amann, R.I., Ludwin, W., Schleifer, K.H., 1995. Phylogenetic identification and in situ detection of individual microbial cells without cultivation. Microbiol. Rev. 59, 143-169.

Amann, R.I., Krumholz, L., Stahl, D.A., 1990. Fluorescent oligonucleotide probing of whole cells for determinative, phylogenetic and environmental studies in microbiology. J. Bact. 172, 762-770.

Anthonisen, A.C., Loehr, R.C., Prakasam, T.B.S., Scinath, E.G., 1976. Inhibition of nitrification by ammonia and nitrous acid. J. Water Pollut. Control Fed. 48 (5), 35-52.

Bothe, H., Jost, G., Schloter, M., Ward, B.B., Witzel, K.-P., 2000. Molecular analysis of ammonia oxidation and denitrification in natural environments. FEMS Microbiol. Rev. 24, 673-690.

Che, O.J., Lee, D.S., Jong, M.P., 2003. Microbial communities in activated sludge performing enhanced biological phosphorus removal in a sequencing batch reactor. Water Res. 37, 2195-2205.

Daims, H., Nielsen, P., Nielsen, J.L., Juretschko, S., Wagner, M., 2000. Novel Nitrospira-likes bacteria as dominant nitriteoxidizers in biofilms from wastewater treatment plants: diversity and in situ physiology. Water Sci. Technol. 41 (4-5), 85-90.

Davies, S.L., Wittenbury, R., 1970. Fine structure of methane and other hydrocarbon utilizing bacteria. J. Gen. Microbiol. 61, 227-232.

Dionisi, H.M., Layton, A.C., Robinson, K.G., Browm, J.R., Gregory, I.R., Parker, J.J., Sayler, G.S., 2002. Quantification of Nitrosomonas oligotropha and Nitrospira spp. using competitive polymerase chain reaction in bench-scale wastewater treatment reactors operating at different solids retention times. Water Environ. Res. 74 (5), 462-469.

Gao, M.C., Yang, M., Hu, J.Y., Shao, B., Zhang, H.F., Li, H.Y., 2003. Identification of ubiquinones and menaquinones in activated sludge by liquid chromatography-atmospheric pressure chemical ionization mass spectrometry. J. Chromatogr. A 1007, 31-37. 
Gao, M.C., Yang, M., Li, H.Y., Wang, Y.M., Pan, F., 2004. Nitrification and sludge characteristics in a submerged membrane bioreaction on synthetic inorganic wastewater. Desalination 170 (2), 177-185.

Hasar, H., Kinaci, C., Unlü, A., 2002. Viability of microbial mass in a submerged membrane bioreactor. Desalination 150, 263-268.

Hasar, H., Kinaci, C., Unlü, A., 2003. Production of nonbiodegradable compounds based on biomass activity in a submerged ultrafiltration hollow fibre membrane bioreactor treating raw whey. 39 (11), 1631-1638.

Hedrick, D.B., White, D.C., 1986. Microbial respiratory quinines in the environment a sensitive liquid chromatographic method. J. Microbiol. Methods 5, 243-254.

Hesselsoe, M., Brandt, K.K., Sorensen, J., 2001. Quantisation of ammonia oxidizing bacteria in soil using microcolony technique combined with Euorescence in situ hybridization (MCFU-FISH). FEMS Microbiol. Ecol. 38, 87-95.

Hiraishi, A., Ueda, Y., Ishihara, J., Mori, T., 1996. Comparative lipoquinone analysis of influent sewage and activated sludge by high-performance liquid chromatography and photodiode array detection. J. Gen. Appl. Microbiol. 42, 457-469.

Hiraishi, A., 1999. Isoprenoid quinines as biomarkers of microbial populations in the environment. J. Biosci. Bioeng. 88 (5), 449-460.

Hu, H.Y., Lim, B.R., Goto, N., Bhupathiraju, V.K., Fujie, K., 2001. Characterization of microbial community in an activated sludge process treating domestic wastewater using quinone profiles. Water Sci. Technol. 43 (1), 99-106.

Juretschko, S., Timmermann, G., Schmid, M., Schleifer, K.H., Pommerening-Roser, A., Koops, H.P., Wagner, M., 1998. Combined molecular and conventional analyses of nitrifying bacterium diversity in activated sludge: Nitrosococcus mobilis and Nitrospira-like bacteria as dominant populations. Appl. Environ. Microbiol. 64 (8), 3042-36051.

Kurisu, F., Satoh, H., Mino, T., Matsuo, T., 2002. Microbial community analysis of thermophilic contact oxidation process by using ribosomal RNA approaches and the quinone profile method. Water Res. 36, 429-438.

Li, H.Y., Yang, M., Zhang, Y., Liu, X.C., Gao, M.C., kamagata, Y., 2005. Comparison of nitrification performance and microbial community between submerged membrane bioreactor and conventional activated sludge system. Water Sci. Technol. 51 (6-7), 535-543.

Lim, B.-R., Ahn, K.-H., Songprasert, R., Lee, S.-H., Kim, M.-J., 2004. Microbial community structure in an intermittently aerated submerged membrane bioreactor treating domestic wastewater. Desalination 161, 145-153.

Luxmy, B.S., Nakajima, F., Yamamoto, K., 2000. Analysis of bacterial community in membrane-separation bioreactors by fluorescent in situ hybridization (FISH) and denaturing gradient gel electrophoresis (DGGE) techniques. Water Sci. Technol. 41 (10-11), 259-268.

Lübbeke, S., Vogelpohl, A., Dewjanin, W., 1995. Wastewater treatment in a biological high-performance system with highbiomass concentration. Water Res. 29 (3), 793-802.

Mobarry, B.K., Wagner, M., Urbain, V., Rittmann, B.E., Stahl, D.A., 1996. Phylogenetic probes for analysing abundance and spatial organization of nitrifying bacteria. Appl. Enviorn. Microbiol. 62 (6), 2156-2162.

Muller, E.B., Southamer, A.H., van Verseveld, H.W., Eikelboom, D.H., 1995. Aerobic domestic waste water treatment in a pilot plant with complete sludge retention by cross-flow filtration. Water Res. 29 (4), 1179-1189.

Persson, F., Wik, T., Sorensson, F., Hermansson, M., 2002. Distribution and activity of ammonia oxidizing bacteria in a large full-scale trickling filter. Water Res. 36, 1439-1448.

Purkhold, U., Pommerening, R.A., Juretschko, S., Schmid, M.C., Koops, H.-P., Wanger, M., 2000. Phytogeny of all recognized species of ammonia oxidizers based on comparative $16 \mathrm{~S}$ rRNA and amoA sequence analysis: implications for molecular diversity serveys. Appl. Environ. Microbiol. 66 (12), 53685382.

Rittmann, B.E., 2002. The role of molecular methods in evaluating biological treatment processes. Water Environ. Res. 74, 421-427.

Rosenberger, S., Krilger, U., Witzig, R., Manz, W., Szewzyk, U., Kraume, M., 2002. Performance of a bioreactor with submerged membranes for aerobic treatment of municipal wastewater. Water Res. 36, 413-420.

Schramm, A., Beer, D., Wagner, M., Amann, R., 1998. Identification and activities in situ of Nitrosospira and Nitrospira spp. as dominant populations in a nitrifying fluidized bed reactor. Appl. Environ. Microbiol. 64 (9), 3480-3485.

Stamper, D.M., Walch, M., Jacobs, R.N., 2003. Bacterial population changes in a membrane bioreactor for graywater treatment monitored by denaturing gradient gel electrophoretic analysis of 16S rRNA gene fragments. Appl. Enviorn. Microbiol. 69 (2), 852-860.

Stehr, G., Bottcher, B., Dittberner, P., Gath, G., Koops, H.-P., 1995. The ammonia-oxidizing nitrifying population of the River Elbe estuary. FEMS Microbiol. Ecol. 17, 177-186.

Stephen, J.R., McCaig, A.E., Smith, Z., Embley, T.M., Prosser, J.I., 1996. Molecular diversity of soil and marine 16S rRNA gene sequences related to P-subgroup ammonia-oxidizing bacteria. Appl. Environ. Microbiol. 62, 4147-4154.

Takamiya, K.-I., Nishimura, M., 1975. Nature of photochemical reactions in chromatophores of chromatium D III heterogeneity of the photo synthetic units. Biochim. Biophy. Acta (BBA)-Bioenergetics 396 (1), 93-103.

Tang, J.Ch., Kanamori, T., Inoue, Y., Yasuta, T., Yoshida, Sh., Katayama, A., 2003. Changes in the microbial community structure during thermophilic composting of manure as detected by the quinone profile method. Process Biochem. 39 (12), 1999-2006.

Teske, A., Aim, E., Regan, J.M., Toze, S., Rittmann, B.E., Stahl, D.A., 1994. Evolutionary relationships among ammonia- and nitriteoxidizing bacteria. J. Bacteriol. 176 (21), 6623-6630.

Tsuneda, S., Nagano, T., Hoshino, T., Ejiri, Y., Noda, N., Hirata, A., 2003. Characterization of nitrifying granules produced in an aerobic upflow fluidized bed reactor. Water Res. 37, 4965-4973.

Wagner, M., Rath, G., Koops, H.-R., Flood, J., Amann, R., 1996. In situ analysis of nitrifying bacteria in sewage treatment plants. Water Sci. Technol. 34, 237-244.

Wagner, M., Rath, G., Amann, R., Koops, H.-R., Schleifer, K.-H., 1995. In situ identification of ammonia-oxidizing bacteria. Syst. Appl. Microbial. 18, 251-264. 
Wallner, G., Amann, R.I., Beisker, W., 1993. Optimizing fluorescent in situ hybridization with rRNA-targeted oligonucleotide probes for flow cytometric identification of microorganisms. Cytometry 14, 136-143.
Witzig, R., Manz, W., Rosenberger, S., Kruger, U., Kraume, M., Szewzyk, U., 2002. Microbiological aspects of a bioreactor with submerged membranes for aerobic treatment of municipal wastewater. Water Res. 36, 394-402. 